\title{
The Impact of Ostracism on Work Effort: A Comparison between Turkish and Azerbaijani Employees
}

\author{
Erman Türkmen \\ Research Assistant, Department of Human Resource Management \\ School of Business, İstanbul University, Turkey \\ Altan Doğan (Corresponding author) \\ Assistant Professor, Department of Human Resource Management \\ School of Business, İstanbul University, Turkey \\ Email: altand@istanbul.edu.tr \\ Ayşegül Karaeminoğulları \\ Visiting Researcher, Department of Management, \\ School of Business Administration, Portland State University, USA
}

Received: November 15, 2016 Accepted: December 08, 2016 Published: December 16, 2016

doi:10.5296/ijhrs.v6i4.10300 URL: http://dx.doi.org/10.5296/ijhrs.v6i4.10300

\begin{abstract}
Ostracism is a critical issue with its influence on employee motivation, employee performance and hence on organizational success. The purpose of this cross cultural study is to investigate whether being a victim of ostracism in the workplace has an impact on work effort or not. Additionally, it aims a comparative examination of differences between Turkish and Azerbaijani employees in terms of workplace ostracism and work effort, with regard to factors such as gender and sector of employment. Results confirm that, experiencing ostracism in the workplace decreases the amount of work effort in a sample of 240 Turkish and Azerbaijani employees. Furthermore, the results also show that, Azerbaijani employees are being subject to workplace ostracism behaviors more than Turkish employees and there are statistically significant differences between male and female employees in terms of workplace ostracism and work effort.
\end{abstract}

Keywords: Workplace Ostracism, Work Effort, Turkish Employees, Azerbaijani Employees 


\section{Introduction}

Ostracism is a social control/punishment mechanism, which targets on individuals' belongingness emotions and wound them with loneliness. Even though it can take place in all social contexts, workplace provides even a more suitable environment for ostracism since several individuals operate together for a certain purpose in a setting of conflicting interests. Even if its concrete negative effects may not be observed overtly as in physical punishments, ostracism in the workplace apparently have substantially unfavorable impacts on individuals' psychological well-beings, attitudes, work behaviors, and success levels. It is also referred as a concept, which indirectly and negatively affects organizational performance.

A further factor which ostracism may have an influence on at workplace is the effort levels of employees on the job. Employees who are ostracized at workplace have the potential to experience unpleasant emotions such as sadness, withdrawal, depression, anger, and anxiety all of which may cause employees to devote less effort on the job. Rising on this ground, this study investigates the impact of ostracism on the level of effort devoted by employees at workplace. The study is carried out on Azerbaijani and Turkish employees so that the current state of the citizens of these two countries in terms of their ostracism and work effort levels can be revealed. Furthermore, the possible differences between Azerbaijani and Turkish employees will be examined.

\section{Literature Review}

\subsection{Ostracism in the Workplace}

Ostracism is to be ignored, excluded, received silent treatment or rejected by one or more individuals (Williams, 2007: 236; Williams, Nida, 2011: 71). "The cold shoulder," "avoiding," "shunning," "treat with ignore," "being sent to Coventry," "the silent treatment," "exile," "banishment," "expulsion," "time-out," and "silencing" are some of the many terms used to describe ostracism (Williams, 2001: 7-8). Ostracism, as survey results support, is a universal experience. Most individuals get involved in ostracism either as the victim or as the perpetrator (Ferris, et. al., 2008: 2).

Ostracism in the workplace more specifically, is being ignored and excluded in the organization or in the work group (Kreitner, 2009: 407). Hitlan, et.al. describe ostracism in the workplace "as the exclusion, rejection, or ignoring of an individual (or group) by another individual (or group) that, hinders one's ability to establish or maintain positive interpersonal relationships, work-related success, or favorable reputation within one's place of work." (Hitlan, et. al., 2006: 217). Feeling of isolation and loneliness of ostracized people in the workplace appear as a result of acts such as being ignored by some others, being the target of an expression of others' anger or disapproval by maintaining aloof silence, being given silent treatment by coworkers, not being socially welcomed, not being accepted in or invited to events outside of working hours (O'Reilly, Robinson, 2009: 1). Therefore, ostracism in the workplace can be accepted as a form of passive counterproductive behavior which has the potential to harm either the organization itself or its employees (Hitlan, et.al., 2006: 57).

Ostracism has two major forms, intentional and unintentional ostracism. Unintentional 
ostracism may arise from pensiveness or preoccupation such as not being acknowledged in an elevator or remaining unacknowledged in a crowded meeting room. Unintentional ostracism may also progress more naturally, being role prescribed, as in the example of a waiter refilling drink glasses in a cafe and not being acknowledged by those being served. From this aspect, therefore, there is also a view which supports the idea that unintentional ostracism cannot be counted as pure ostracism. Intentional ostracism, on the other hand, is a form of action which is performed under the influence of punishment or protection motives. Penalizing an employee who contradicts with group norms exemplifies the punishment motive behind ostracism whereas trying to be an in-group member by breaking off communication with an employee whose behaviors are against the group norms exemplifies the protection motive behind ostracism (Williams, Zadro, 2005: 9). With this aspect ostracism is also being considered as a function of behaviors that form mobbing (Erdem, Parlak, 2010: 266). Though ostracism should be taken into consideration with a unique perspective because its negative effects and damages are not as obvious as in other mobbing behaviors (pounding, insult, sexual harassment, etc.) and because it is not easy to define, verify, or to prove.

According to Williams, ostracism is probably one of the most frequently applied social punishment method since it is regarded as the most humanistic and nondestructive one when compared to its alternatives such as physical attacks and so forth (Neubert, 2005). Even though its effects are not as harsh as in physical and/or verbal attacks, ostracism may cause extreme pain and can be offending and hurtful (Williams, Nida, 2011: 71). It gets a blow in the fulfillment of psychological needs by reducing the possibilities of social interaction $(\mathrm{Wu}$, et. al., 2012: 178). Research points out that even the minimum levels and types of ostracism results in feelings of pain and distress (Williams, 2007: 236). Ostracism usually threatens some fundamental needs of individuals such as belongingness, self-esteem, control, and meaningful existence (Sommer, et. al., 2001: 226; Williams, 2007: 236; Jamieson, et. al., 2010: 690; Wittenbaum, et. al., 2010: 331). The ostracized employee may lose the sense of relatedness within the workplace in time in the case that s/he is not being recognized by others, s/he is not being approved by others, s/he is not being accepted by others, s/he is not receiving any response, reply, reaction or reciprocation, or in the case that s/he is not able to interrelate with others. Since self-esteem is partially affected by individual's socialization status, being ostracized also diminishes self-esteem. Fulfilling the need to control will turn out to be harder as well because individuals will not be responding to the ostracized employee's efforts to attract attention or to join groups. Furthermore, ostracism in the workplace will cause individuals to question the meaning of their own existences, threatening their existence needs (Jamieson, et. al., 2010: 690; Sommer, et. al., 2001: 226).

The level of employee ostracism may differ from one case to another. Some employees may be the subject to ostracism always and in all ways, being completely ostracized. Meanwhile, some employees may be partially ostracized, being excluded or ignored from time to time (Jones, et. al., 2009: 158).

Ostracism at workplace has substantial negative outcomes on both employees and companies. Ostracism at workplace; may deteriorate employees' psychological health (depression, anxiety, emotional exhaustion, and work stress); may breed negative work attitudes (job 


\section{Macrothink}

International Journal of Human Resource Studies

ISSN 2162-3058

2016, Vol. 6, No. 4

dissatisfaction, lower commitment); may give rise to withdrawal behaviors (job quitting, job seeking); may result in deviance at work (organizational and interpersonal deviance) and may cause a decline in the employee's performance (Wu, et. al., 2011: 24). In addition to all these, findings point out that ostracism may also have negative impacts on physical health conditions.

\subsection{Work Effort}

Since effort is a quite complex construct, which is an internal activity, unstable, inherently subjective, hypothetical, and not easy to observe, it is a challenge to exactly define and measure this construct. (Yeo, Neal, 2004: 231). In the broadest framework, effort means the power exerted to complete or accomplish a task and refers to the level of energy (either pyshical or mental) used to fulfill a job duty (Byars, Rue, 2008: 216; Rue, Byars: 2009: 384; Sakurai, Jex, 2012: 152; Yeo, Neal, 2004: 231). It also represents a different construct than the skills, abilities or experiences that, an employee depend on while doing a specific job. Based on the literature; effort can be considered either as the actual amount of energy an employee consumes on the job or as the level of energy needed to successfully accomplish that job (Bielby, Bielby, 1988: 1032,1036). In this study "effort" is addressed independent of the demands of the job, only referring to the total amount of energy put forth by employees in order to complete their jobs.

Effort is also thought as a form of behavior performed by employees in parallel with their own will. Indeed, the employees may still keep on putting effort even when they believe their effort level is already enough to fulfill the performance being expected from themselves and this can be characterized as discretionary effort (Kmec, Gorman, 2010: 10).

Within the framework of this study, actual effort is conceived as an important indicator and evidence of individual performance and it is included as the dependent variable of the research. Because, the level of employee effort, together with capacity and opportunity, are principal components and determinants of individual performance (Blumberg, Pringle, 1982: 562). In other words, the level and quality of an individual's work performance comprises three components: (1) capacity to perform, (2) effort or willingness to perform, and (3) opportunity or the environmental factors (See Table 1). 
Table 1. Principle Components of Individual Performance

Factors $\quad$ Variables

Capacity to perform Ability, age, health, knowledge, skills, intelligence, level of education, endurance, stamina, energy level, motor skills

Willingness perform (or effort) to Motivation, job satisfaction, job status, anxiety, legitimacy of participation, attitudes, perceptions, self-image, personality, norms, values, expectations, emotions

Opportunity perform to Tools, equipment, materials and supplies, working conditions, behaviors of managers, supervisors and co-workers, mentorship, organizational rules, policies and procedures, time, pay

Source: Melvin Blumberg, Charles D. Pringle, "The Missing Opportunity in Organizational Research: Some Implications for a Theory of Work Performance", Academy of Management Review, 7-4, 1982, s.562.

In this study the main concern is on how the level of performance fluctuates when capacities of employees and opportunities they have at work are assumed to be equal. It is inevitable that, different companies included in the sample will vary in terms of opportunities presented to their employees. Furthermore the capacity to perform each task may differ to a great extent from one position to another. With this in mind, a model of performance including capacity and opportunity as components is apparently prone to errors and inadequate for meaningful individual performance comparisons. For example, two employees from two different companies may be considered to have equal performances while one has devoted much less effort but performed equally due to the opportunities present at his/her company. In order to prevent such inconveniences, opportunity and capacity components of performance are assumed to be constant in this study. Effort is accepted as the principle indicator of individual performance.

There is extensive empirical repertoire on ostracism, its antecedents and consequences derived from research and studies mostly approaching the concept from psychological/social psychological aspects (Gruter, Masters, 1986; Leary, 1990; Jones, 1990; Baumeister, Tice, 1990; Twenge, et. al., 2002; Baumeister, et. al., 2002; Twenge, et. al., 2003; Zadro, et. al., 2006; Van Beest, Williams, 2006; Chow, et. al., 2008; Oaten, et. al., 2008), some of which focus on the issue in social group contexts (Van Prooijen, et. al., 2004; Gonsalkorale, Williams, 2007; Krill, et. al., 2008; Jones, et. al., 2011; Stout, Dasgupta, 2011), some in the electronic context (Williams, et. al., 2000; Williams, et. al., 2002; Smith, Williams, 2004; Goodacre, Zadro, 2010; Karlen, Daniels, 2011; Kassner, et. al., 2012; Filipkowski, Smyth, 
2012), and some in groups composed of children (Benenson, et. al., 2008; Over, Carpenter, 2009; Masten, et. al., 2010; Twyman, et. al., 2010; Crowley, et. al., 2010; Abrams, et. al., 2011; Pharo, et. al., 2011; Hawes, et. al., 2012; Barkley, et. al., 2012; Salvy, et. al., 2012). There is comparatively little research on ostracism at work and among employees. Ostracism within the workplace context appears to be recently but increasingly developing due to its potential effects on work outcomes.

One research investigating the association of ostracism with employee effort and/or performance is conducted on 262 full-time employees by Fox and Stallworth (2005). Among the respondents evaluating over five years, $66 \%$ declared to have felt systematically ignored while $29 \%$ indicated that when they entered a room other people intentionally left the area (Wu, et. al., 2012: 178).

Williams and Sommer (1997) revealed that being ostracized by group friends had very little impact on effort levels of male targets while it increased the effort levels of female targets. Ostracized females, compared to the females who have not been a target of ostracism, are found to exhibit less social loafing and work harder. Males tend to exhibit social loafing regardless of being ostracized or not.

Geller et. al. (1974) found that participants work less after experiencing ostracism and that they tend to benefit from being a target of ostracism (Kerr, et. al., 2008: 737). The impact of ostracism on work attitudes and behaviors is supported by Hitlan, et. al.(2006: 58) as well. Their findings point out that targets of ostracism tend to have lower levels of organizational commitment and exhibit lower levels of organizational citizenship behaviors. O'Reilly and Robinson (2009)'s findings point out that ostracism negatively affects belongingness and connectedly relates to higher withdrawal behaviors and lower performance. In their research Baumeister, et. al. (2002) demonstrate that social exclusion impairs cognitive performance (O'Reilly, Robinson, 2009: 1). In the research of Lustenberger and Jagacinski (2010) ostracized participants are found to have lower performance. The research by Ferris, et. al. (2008) reveals a negative relationship between ostracism and role performance. Findings of Leung, et. al. (2011) show that a negative relationship exists between ostracism at workplace and service performance. According to the results of the research conducted by Wu, Wei and Hui (2011), ostracism at work is negatively correlated with employee work performance. Leung, et. al.'s (2011) study reveal that ostracism at workplace negatively affects employee performance via work engagement in service organizations.

\section{Purpose and the Significance of the Research}

Ostracism is a concept, which naturally exists even in groups of only two and thus has a history as old as humanity. It is a very common workplace behavior both because it is considered as a tool, which maintains the acceptance of norms, and because it is admitted as one of the least harmful punishment methods. Ostracism is like an umbrella term, which includes a variety of behaviors including either minor acts such as silent treatment (refusing communication, not responding), avoiding eye contact or severe and more obvious acts such as exile and banishment (Ferris, et. al., 2008). With these characteristics, ostracism is naturally pretty common in the organizational settings where many employees work together 
despite their conflicting interests. Furthermore, ostracism is a critical issue with its great influence on employee motivation, employee performance and hence on organizational success. Due to its prevalence, universality and potential impacts, ostracism has been the focus of this study. Effort in the workplace, the dependent variable of the research, is included in the model since it is accepted as an important determiner of individual performance and so an important indicator of organizational success.

The value of the research lies in its effort to shed light on ostracism, which is relatively an unknown and invisible phenomenon of the workplace. The lack of studies in Turkey and Azerbaijan settings generates additional benefits of the findings. Furthermore the most important contribution of the study is probably that it holds a comparative approach, which circuitously enriches not only the literature but also the practice of workplace.

In this context, the hypotheses are developed as follows:

$\mathrm{H} 1$ : There is a negative correlation between workplace ostracism and work efforts devoted by employees.

H2: Workplace ostracism affects the level of work effort devoted by employees.

H3: There is a difference between two nationality groups in terms of the level of workplace ostracism they are being exposed to.

H4: There is a difference between two nationality groups in terms of the level of work effort they put.

H5: There are gender differences among both Turkish and Azerbaijani employees in terms of the amount of workplace ostracism experienced and level of work effort put forth.

H6: There are sectorial differences (when classified as public or private) among both Turkish and Azerbaijani employees in terms of the amount of workplace ostracism experienced and level of work effort put forth.

\section{Methods}

\subsection{Procedures}

The research data is collected via a survey questionnaire. The first section of the questionnaire included the scales, which intended to measure experienced ostracism at workplace and work effort. The second section of the questionnaire was composed of a list of questions collecting information on the demographic characteristics of the sample (such as sector, age, gender, highest education, marital status, etc.) The questionnaire was adapted both to Turkish and Azerbaijani. The questionnaires were distributed both physically and electronically to the participants and were collected the same way as in distribution. Meanwhile, a website had been set up so that desirous participants fill in the questionnaire completely online.

In order to measure the level of ostracism experienced by employees, we depended on Workplace Ostracism Scale which is developed in 2008 by D. Lance Ferris et.al. The 
dependent variable of the research, work effort, is measured by the 10 item Work Effort Scale developed by Rein De Cooman et. al. (2009). In the research questionnaire, both constructs (ostracism and work effort) were measured by seven point Likert scales ranging from 1: Never, 7: Always and 1: Completely Disagree, 7: Completely Agree. All data were analyzed in SPSS 17.0 (SPSS, Chicago, IL, USA). The descriptive analysis used included arithmetic mean and standard deviations. In addition to descriptive analysis, the reliability values (Cronbach's Alpha) of the two scales were calculated separately. In order to investigate the relationship between being ostracized at workplace and work effort, correlation analysis were followed by regression analysis. The ostracism and work effort levels of employees of the two countries had been compared by t-tests. In order to test the reliability of the measurement, Cronbach's Alpha Coefficients are calculated for each scale. The Cronbach's Alpha Coefficient of the Workplace Ostracism Scale is found to be $\alpha: 0.893$ whereas the Cronbach's Alpha Coefficient of the Work Effort Scale is calculated to be $\alpha: 0.924$. Both values are above 0.7 which is the most widely cited minimum value considered as acceptable for the Cronbach's Alpha coefficient in social science researches. (Kalayc1 et.al., 2005: 405). Depending on the results, both of the scales can be qualified as highly reliable.

\subsection{Sample}

The impact of being ostracized in the workplace on work effort is investigated on a sample of Turkish and Azerbaijani employees reached via convenience sampling. In order to keep the framework of the research as wide as possible, no restrictions are applied in terms of sector, or so forth. In the survey research conducted, a total of 257 completed questionnaires were collected out of which 17 were eliminated due to missing data. A total number of 240 employees out of which 136 are Turkish and 104 are Azerbaijani have participated in the study. The participants are a mixture of public and private sector employees as well as being a combination of both service and production/industry employees. 85 of the participants are female (35.4\%), 155 are male (64.6\%). 128 of the participants are married (53.3\%) whereas 112 of them are single $(46.7 \%)$. Depending on the highest education level achieved, participants vary to a great extent. 14 participants (5.8\%) are elementary school, $37(15.4 \%)$ are high school, $137(57.1 \%)$ are university, and $52(21.7 \%)$ are graduate graduates. 88 of the participants are working in public organization and institutions (36.7\%) and 152 of them are working in private companies (63.3\%). 45 participants are employed in the production/industry sector employees $(18.8 \%)$ whereas 195 participants are employed in the service sector $(81.3 \%)$. The number of employees who work for a period of less than one year in the same company is $52(21.7 \%)$, who work for 1 to 5 years is $97(40.4 \%)$, who work for 5 to 10 years is $53(22.1 \%)$, who work for 10 to 15 years is $14(5.8 \%)$ and who work for 15 year or more in the same company is $24(10.0 \%)$. 84 out of 136 Turkish employees participating in the research are males (61.8\%), 52 are females $(38.2 \%) .65$ of the Turkish participants are married (47.8\%) and 71 are single (52.2\%); 5 are elementary school graduates (3.7\%), 24 are high school graduates (17.6\%), 76 are university (55.9\%) and 31 are graduate $(22.8 \%)$ graduates. 64 Turkish participants are employed in the public sector $(47.1 \%)$ and 72 are employed in the private sector (52.9\%); 117 are service sector employees $(86.0 \%)$ whereas 19 are production/industry sector employees (14.0\%). 71 out of 104 Azerbaijani 
employees participating in the research are males (68.3\%), 33 are females (31.7\%). 63 of the Azerbaijani participants are married (60.6\%) and 41 are single (39.4\%); 22 are elementary school and high school graduates $(21.2 \%), 61$ are university $(58.7 \%)$ and 21 are graduate (20.2\%) graduates. 24 Azerbaijani participants are employed in the public sector $(23.1 \%)$ and 80 are employed in the private sector (76.9\%); 78 are service sector employees $(75 \%)$ whereas 26 are production/industry sector employees (25\%). (See Table 2.)

Table 2. Demographics of the Sample

\begin{tabular}{|c|c|c|c|c|c|c|c|}
\hline & & \multicolumn{2}{|c|}{$\begin{array}{l}\text { Total } \\
n=240\end{array}$} & \multicolumn{2}{|c|}{$\begin{array}{l}\text { Turkish } \\
n=136\end{array}$} & \multicolumn{2}{|c|}{$\begin{array}{l}\text { Azerbaijani } \\
n=104\end{array}$} \\
\hline \multicolumn{2}{|c|}{ Demographics } & Freq. & $(\%)$ & Freq. & $(\%)$ & Freq. & $(\%)$ \\
\hline \multirow[t]{2}{*}{ Gender } & Female & 85 & 35.4 & 52 & 38.2 & 33 & 31.7 \\
\hline & Male & 155 & 64.6 & 84 & 61.8 & 71 & 68.3 \\
\hline \multirow{2}{*}{$\begin{array}{l}\text { Marital } \\
\text { Status }\end{array}$} & Married & 128 & 53.3 & 65 & 47.8 & 63 & 60.6 \\
\hline & Single & 112 & 46.7 & 71 & 52.2 & 41 & 39.4 \\
\hline \multirow[t]{4}{*}{ Education } & Elementary & 14 & 5.8 & 5 & 3.7 & 9 & 8.7 \\
\hline & High School & 37 & 15.4 & 24 & 17.6 & 13 & 12.5 \\
\hline & University & 137 & 57.1 & 76 & 55.9 & 61 & 58.7 \\
\hline & Graduate & 52 & 21.7 & 31 & 22.8 & 21 & 20.2 \\
\hline \multirow[t]{2}{*}{ Sector } & Public & 88 & 36.7 & 64 & 47.1 & 24 & 23.1 \\
\hline & Private & 152 & 63.3 & 72 & 52.9 & 80 & 76.9 \\
\hline \multirow[t]{2}{*}{ Field } & Service & 195 & 81.3 & 117 & 86 & 78 & 75.0 \\
\hline & Production/Industry & 45 & 18.7 & 19 & 14 & 26 & 25.0 \\
\hline \multirow[t]{3}{*}{ Seniority } & Less than 1 year & 52 & 21.7 & 32 & 23.5 & 20 & 19.2 \\
\hline & 1-5 Years & 97 & 40.4 & 42 & 30.9 & 55 & 52.9 \\
\hline & 5-10 Years & 53 & 22.1 & 34 & 25.0 & 19 & 18.3 \\
\hline
\end{tabular}




$\begin{array}{lcccccc}\text { 10-15 Years } & 14 & 5.8 & 7 & 5.1 & 7 & 6.7 \\ \text { More than 15 Years } & 24 & 10 . & 21 & 15.4 & 3 & 2.9\end{array}$

\section{Results}

\subsection{Analyses}

According to the descriptive statistical analysis (arithmetic means and standard deviations) of the scales used in the research; considering the complete set of participants, the arithmetic mean of the Workplace Ostracism Scale is found to be 1.480 and the standard deviation is calculated to be 0.59 . Arithmetic mean and standard deviation values for the Work Effort Scale are found to be 6.195 and 0.86 respectively (See Table 3). When the overall means for the Turkish and Azerbaijani participants are examined, it is observed that participants are exposed to a very low level of ostracism. On contrary, the mean of the work effort scale is found to be substantially high.

According to the separate analysis of scale means of the Turkish and Azerbaijani employees, the arithmetic mean of the Workplace Ostracism Scale for Turkish employees is 1.333 (std. deviation 0.50), for Azerbaijani employees is 1.672 (std. deviation 0.64). The arithmetic mean and standard deviation values related to the Work Effort Scale is found to be 6.158 (std. deviation 0.98) for Turkish employees and 6.244 (std. deviation 0.68) for Azerbaijani employees (See Table 3).

Table 3. Mean and Standard Deviation Values of the Scales

\begin{tabular}{llll}
\hline & $\mathrm{n}$ & $\mathrm{M}$ & $\mathrm{S} . \mathrm{D}$. \\
\hline Workplace Ostracism & 240 & 1.480 & .59 \\
Turkish Employees & 136 & 1.333 & .50 \\
$\quad$ Azerbaijani & 104 & 1.672 & .64 \\
$\begin{array}{l}\text { Employees } \\
\text { Work Effort }\end{array}$ & 240 & 6.195 & .86 \\
Turkish Employees & 136 & $6, .158$ & .98 \\
$\quad$ Azerbaijani Employees & 104 & 6.244 & .68 \\
\hline
\end{tabular}

The comparison of the scale means of Turkish and Azerbaijani employees show that Azerbaijani employees are exposed to slightly a higher level of ostracism at work. In addition, the work effort levels of Azerbaijani employees are found to be slightly higher relative to Turkish employees. It is a remarkable finding that Azerbaijani employees, who experience 
more ostracism at work than Turkish employees, also devote relatively more work effort.

\subsubsection{Hypothesis 1}

Hypothesis 1 proposed that there would be a negative correlation between workplace ostracism and work efforts devoted by employees. Pearson Correlation Analysis results indicate that, a negative but weak correlation (-.231) is found to exist with a significance level of 0.05 between these two variables. (See Table 4.)

Table 4. Pearson Correlation Analysis Results

Pearson Correlation

Sig. (Two-tailed)

$\mathrm{N}$
$.000 *$

240

* The result is statistically significant in the 0.05 significance level.

\subsubsection{Hypothesis 2}

For the investigation of the possible impact of workplace ostracism on work efforts of employees, Regression Analysis is run. The Regression model is found to be statistically significant $(F=13.447$; significance level p: $0.000<0.05)$. The Anova significance value of workplace ostracism, the independent variable of the model, is calculated to be 0.000 $(\mathrm{t}=-3.667)(\mathrm{p}: 0.000<0.05)$ which supports that workplace ostracism variable has a significant impact on work effort variable. $\mathrm{H} 2$ hypothesis is accepted.

As mentioned earlier in the Correlation analysis results, the correlation value between these two variables is -0.231 . Workplace ostracism explains $0.53 \%$ of the variance (change) in work effort. In other words, indicating ostracism level that employees are exposed to at their workplaces provides predicting work effort with a $0.53 \%$ accuracy (Altunışık et.al., 2004: 204). With regard to this finding, a one unit increase in workplace ostracism results in a decrease by 0.337 in work effort. The estimation result of the model can be formulized as: Work Effort $=6.695+(-0.337 \times$ Workplace Ostracism $)$

Table 5. Regression Analysis Results

\begin{tabular}{lccccc}
\hline & B & Std. Error & Beta & T & Sig. \\
\hline Constant $)$ & 6.695 & .146 & & 45.704 & .000 \\
Workplace & -.337 & .092 & -.231 & -3.667 & .000 \\
Ostracism & & & & & \\
\hline R: 0.231 & $\mathrm{R}^{2}: 0.053$ & $\mathrm{~F}: 8.345$ & $\mathrm{p}: 0.000$ & &
\end{tabular}




\subsubsection{Hypothesis 3}

Hypothesis 3 proposed that, there would be difference between Turkish and Azerbaijani employees in terms of their workplace ostracism levels. The results of the t-Test Analysis indicate that, a significant difference between these two groups is found to exist in the 0.05 significance level. Depending on this result it can be concluded that, Azerbaijani employees are being subject to workplace ostracism behaviors more than Turkish employees. (See Table $6)$.

Table 6. t-Test Analysis Results for Turkish and Azerbaijani Employees

\begin{tabular}{llllll}
\hline & & $\mathrm{n}$ & $\mathrm{M}$ & S.D. & p-value \\
\hline $\begin{array}{l}\text { Workplace } \\
\text { Ostracism }\end{array}$ & Turkish & 136 & 1.337 & 0.50 & $.000^{*}$ \\
\cline { 2 - 6 } & Azerbaijani & 104 & 1.672 & 0.64 & .421 \\
\hline Work Effort & Turkish & 136 & 6.158 & 0.98 \\
\cline { 2 - 6 } & Azerbaijani & 104 & 6.244 & 0.68 & \\
\hline
\end{tabular}

* The result is statistically significant in the 0.05 significance level.

\subsubsection{Hypothesis 4}

Hypothesis 4 proposed that there would be significant difference between Turkish and Azerbaijani employees in terms of their work effort levels. The t-Test results indicate that these two groups are found to be statistically equivalent in the 0.05 significance level. (See Table 6). While work effort level of Azerbaijani employees is found to be higher than Turkish employees, this difference is not supported to be statistically significant.

\subsubsection{Hypothesis 5}

t-Test analyses are run to see the differences within both Turkish and Azerbaijani employees, with regard to factor gender, as given in the Table 7 . The results indicate that, there are statistically significant differences (in the 0.05 significance level) between male and female Turkish employees, in terms of workplace ostracism they experienced, and work effort they put forth. Depending on these results it can be concluded that, Turkish male employees experience relatively higher levels of workplace ostracism compared to Turkish female employees, and Turkish female employees put forth more work effort in comparison with Turkish male employees.

On the other hand, the significant difference between male and female employees within Azerbaijani employees is found only in terms of workplace ostracism. The results show us that, Azerbaijani female employees are being subject to workplace ostracism relatively more often than Azerbaijani male employees. However, Azerbaijani female and male employees do not differ significantly, in terms of the level of work effort they put forth (See Table 7). 


\subsubsection{Hypothesis 6}

No significant sectorial differences (when classified as public or private) are found for either Turkish or Azerbaijani employees in terms of the amount of workplace ostracism experienced and level of work effort put forth, contrary to what is proposed in Hypothesis 6 (See Table 7).

Table 7. t-Test Analysis Results Between Gender and Sector Among Turkish and Azerbaijani Employees

\begin{tabular}{|c|c|c|c|c|c|}
\hline & & & $\mathrm{n}$ & S.D. & $\mathrm{p}$-value \\
\hline \multirow{8}{*}{$\begin{array}{l}\text { Turkish } \\
\text { Employees }\end{array}$} & \multirow{4}{*}{$\begin{array}{l}\text { Workplace } \\
\text { Ostracism }\end{array}$} & Male & 84 & 1.3940 .58 & \multirow{2}{*}{$-.038 *$} \\
\hline & & Female & 52 & 1.2350 .30 & \\
\hline & & Public & 64 & 1.3460 .38 & \multirow{2}{*}{-.785} \\
\hline & & Private & 72 & 1.3220 .59 & \\
\hline & \multirow[t]{4}{*}{ Work Effort } & Males & 84 & 5.9161 .10 & \multirow{2}{*}{$-.000^{*}$} \\
\hline & & Females & 52 & 6.5480 .557 & \\
\hline & & Public & 64 & 6.1680 .94 & \multirow{2}{*}{-.905} \\
\hline & & Private & 72 & 6.1481 .01 & \\
\hline \multirow{8}{*}{$\begin{array}{l}\text { Azerbaijani } \\
\text { Employees }\end{array}$} & \multirow{4}{*}{$\begin{array}{l}\text { Workplace } \\
\text { Ostracism }\end{array}$} & Male & 71 & 1.5790 .60 & \multirow{2}{*}{$-.030 *$} \\
\hline & & Female & 33 & 1.8710 .72 & \\
\hline & & Public & 24 & 1.7910 .72 & \multirow{2}{*}{-.302} \\
\hline & & Private & 80 & 1.6360 .62 & \\
\hline & \multirow[t]{4}{*}{ Work Effort } & Male & 71 & 6.3020 .57 & \multirow{2}{*}{-.267} \\
\hline & & Female & 33 & 6.1180 .86 & \\
\hline & & Public & 24 & 6.1000 .57 & \multirow{2}{*}{-.237} \\
\hline & & Private & 80 & 6.2870 .71 & \\
\hline
\end{tabular}

* The result is statistically significant in the 0.05 significance level. 


\section{Conclusion}

In this comparative research on Turkish and Azerbaijani employees, the researchers investigated the impact of being ostracized at workplace on employees' work effort levels. The analysis of the data obtained from the sample of a total number of 240 Turkish and Azerbaijani participants revealed that ostracism at workplace is significantly but weakly, negatively correlated with work effort. This result is in parallel with the findings of the literature review, which mainly supports the decrease in employees' work efforts in the case of an increase in the experience of workplace ostracism. Further investigation of these variables via regression analysis put forth that workplace ostracism has a negative impact on work effort.

The researchers also examined the differences between Turkish and Azerbaijani employees. According to the findings, Azerbaijani employees are being ostracized in the workplace more often than Turkish employees. While Azerbaijani employees are found to devote more effort at work compared to Turkish employees, this difference is not at a statistically significant level. Furthermore, Turkish male employees are being subject to workplace ostracism relatively more often than Turkish female employees whereas Turkish female employees devote higher levels of work effort than Turkish male employees.

The researchers also found that, Azerbaijani female employees are being subject to workplace ostracism relatively more often than Azerbaijani male employees. Nevertheless, Azerbaijani female and male employees do not differ significantly, in terms of the level of work effort they put forth. Additionally, depending on the sector (either public or private), Turkish and Azerbaijani employees are found to exhibit no significant differences in terms of the means of workplace ostracism and work effort.

\section{References}

Abrams, D., Weick, M., Thomas, D., Colbe, H., \& Franklin, K. M. (2011). On - line ostracism affects children differently from adolescents and adults. British Journal of Developmental Psychology, 29(1), 110-123.

Altunisik, R., Coskun, R., Bayraktaroglu, S., \& Yildirim, E. ( 2004). Sosyal bilimlerde arastirma yöntemleri : SPSS uygulamalı [Research methods in social sciences: With SPSS applications] (3rd ed.) Sakarya: Sakarya Kitabevi [Sakarya:Sakarya Press].

Barkley, J. E., Salvy, S. J., \& Roemmich, J. N. (2012). The effect of simulated ostracism on physical activity behavior in children. Pediatrics, 129(3), 659-666.

Baumeister, R. F., \& Tice, D. M. (1990). Point-counterpoints: Anxiety and social exclusion. Journal of Social and Clinical Psychology, 9(2), 165-195.

Baumeister, R. F., Twenge, J. M., \& Nuss, C. K. (2002). Effects of social exclusion on cognitive processes: anticipated aloneness reduces intelligent thought. Journal of Personality and Social Psychology, 83(4), 817-827. 
Benenson, J. F., Hodgson, L., Heath, S., \& Welch, P. J. (2008). Human sexual differences in the use of social ostracism as a competitive tactic. International Journal of Primatology, 29(4), 1019-1035.

Bielby, D. D., \& Bielby, W. T. (1988). She works hard for the money: Household responsibilities and the allocation of work effort. American Journal of Sociology, 93(5), 1031-1059.

Blumberg, M., \& Pringle, C. D. (1982). The missing opportunity in organizational research: Some implications for a theory of work performance. Academy of Management Review, 7(4), 560-569.

Byars, L. L., \& Rue, L. W. (2008). Human Resource Management (9th ed.- McGraw-Hill International Edition ed.,). New York: The McGraw-Hill International Companies.

Chow, R. M., Tiedens, L. Z., \& Govan, C. L. (2008). Excluded emotions: The role of anger in antisocial responses to ostracism. Journal of Experimental Social Psychology, 44(3), 896-903.

Cooman, R., De Gieter, S., Pepermans, R., Jegers, M., \& Van Acker, F. (2009). Development and validation of the Work Effort Scale. European Journal of Psychological Assessment, 25(4), 266-273.

Crowley, M. J., Wu, J., Molfese, P. J., \& Mayes, L. C. (2010). Social exclusion in middle childhood: rejection events, slow-wave neural activity, and ostracism distress. Social Neuroscience, 5(5-6), 483-495.

Erdem, M. R., \& Parlak, B. (2010). Ceza Hukuku Boyutuyla Mobbing. [Mobbing from the Criminal Law Perspective], TBB Dergisi [TBB Journal], 88, 261-286

Ferris, D. L., Brown, D. J., Berry, J. W., \& Lian, H. (2008). The development and validation of the Workplace Ostracism Scale. Journal of Applied Psychology, 93(6), 1348-1366.

Ferris, D. L., Berry, J., Brown, D. J., \& Lian, H. (2008, August). When silence isn't golden: Measuring ostracism in the workplace. In Academy of Management Proceedings (Vol. 2008, No. 1, pp. 1-6). Academy of Management.

Filipkowski, K. B., \& Smyth, J. M. (2012). Plugged in but not connected: Individuals' views of and responses to online and in-person ostracism. Computers in Human Behavior, 28(4), 1241-1253.

Gonsalkorale, K., \& Williams, K. D. (2007). The KKK won't let me play: Ostracism even by a despised outgroup hurts. European Journal of Social Psychology, 37(6), 1176-1186.

Goodacre, R., \& Zadro, L. (2010). O-Cam: A new paradigm for investigating the effects of ostracism. Behavior Research Methods, 42(3), 768-774.

Gruter, M., \& Masters, R. D. (1986). Ostracism as a social and biological phenomenon: An introduction. Ethology and Sociobiology, 7(3), 149-158.

Hawes, D. J., Zadro, L., Fink, E., Richardson, R., O'Moore, K., Griffiths, B., \& Williams, K. 
D. (2012). The effects of peer ostracism on children's cognitive processes. European Journal of Developmental Psychology, 9(5), 599-613.

Hitlan, R. T., Cliffton, R. J., \& DeSoto, M. C. (2006). Perceived exclusion in the workplace: The moderating effects of gender on work-related attitudes and psychological health. North American Journal of Psychology, 8(2), 217-236.

Hitlan, R. T., Kelly, K. M., Schepman, S., Schneider, K. T., \& Zárate, M. A. (2006). Language exclusion and the consequences of perceived ostracism in the workplace. Group Dynamics: Theory, Research, and Practice, 10(1), 56-70.

Horwatt, S. S. (1999, June 4), Ostracism, Retrieved September 13, 2012, from http://www.psychologyinfo.com/DrHorwatt/ostracism.htm

Jamieson, J. P., Harkins, S. G., \& Williams, K. D. (2010). Need threat can motivate performance after ostracism. Personality and Social Psychology Bulletin, 36(5), 690-702.

Jones, E. E., Carter-Sowell, A. R., Kelly, J. R., \& Williams, K. D. (2009). I'm out of the loop': Ostracism through information exclusion. Group Processes \& Intergroup Relations, 12(2), 157-174.

Jones, W. H. (1990). Loneliness and social exclusion. Journal of Social and Clinical Psychology, 9(2), 214-220.

Jones, E. E., Carter-Sowell, A. R., \& Kelly, J. R. (2011). Participation matters: Psychological and behavioral consequences of information exclusion in groups. Group Dynamics: Theory, Research, and Practice, 15(4), 311-325.

Kalaycı, S. (2005). SPSS uygulamalı çok değişkenli istatistik teknikleri [Multi-Variate Statistical Methods with SPSS Applications], Ankara: Asil Yayın Dağıtım [Asil Publishing and Distribution].

Karlen, C. E. (2011). Cyberostracism and social monitoring: Social anxiety's effects on reactions to exclusion and inclusion online. Honors Projects. Paper 147. Retrieved September 13, 2012, from http://digitalcommons.iwu.edu/ cgi/viewcontent.cgi? article=1146\&context=psych_honproj

Kassner, M. P., Wesselmann, E. D., Law, A. T., \& Williams, K. D. (2012). Virtually ostracized: Studying ostracism in immersive virtual environments. Cyberpsychology, Behavior, and Social Networking, 15(8), 399-403.

Kerr, N. L., Seok, D. H., Poulsen, J. R., Harris, D. W., \& Messe, L. A. (2008). Social ostracism and group motivation gain. European Journal of Social Psychology, 38(4), 736-746.

Kmec, J. A., \& Gorman, E. H. (2010). Gender and discretionary work effort evidence from the United States and Britain. Work and Occupations, 37(1), 3-36.

Kreitner, R. (2009). Principles of Management, (11th ed.), China: Sorth-Western Cengage Learning. 
Krill, A. L., Platek, S. M., \& Wathne, K. (2008). Feelings of control during social exclusion are partly accounted for by empathizing personality. Personality and Individual Differences, 45(7), 684-688.

Neubert, A. P. (2005, July 27). Cold shoulder, silent treatment do more harm than good. Retrieved September 13, 2012, from http://www.purdue.edu/uns/html3month/ 2005/050727.Williams.exclusion.html

Leary, M. R. (1990). Responses to social exclusion: Social anxiety, jealousy, loneliness, depression, and low self-esteem. Journal of Social and Clinical Psychology, 9(2), 221-229.

Leung, A. S., Wu, L. Z., Chen, Y. Y., \& Young, M. N. (2011). The impact of workplace ostracism in service organizations. International Journal of Hospitality Management, 30(4), 836-844.

Lustenberger, D. E., \& Jagacinski, C. M. (2010). Exploring the effects of ostracism on performance and intrinsic motivation. Human Performance, 23(4), 283-304.

Masten, C. L., Eisenberger, N. I., Pfeifer, J. H., \& Dapretto, M. (2010). Witnessing peer rejection during early adolescence: Neural correlates of empathy for experiences of social exclusion. Social Neuroscience, 5(5-6), 496-507.

Oaten, M., Williams, K. D., Jones, A., \& Zadro, L. (2008). The effects of ostracism on self-regulation in the socially anxious. Journal of Social and Clinical Psychology, 27(5), 471-504.

O'reilly, J., \& Robinson, S. L. (2009, august). The negative impact of ostracism on thwarted belongingness and workplace contributions. In Academy of Management Proceedings (Vol. 2009, No. 1, pp. 1-7). Academy of Management.

Over, H., \& Carpenter, M. (2009). Priming third - party ostracism increases affiliative imitation in children. Developmental Science, 12(3), F1-F8.

Pharo, H., Gross, J., Richardson, R., \& Hayne, H. (2011). Age-related changes in the effect of ostracism. Social Influence, 6(1), 22-38.

Rue, L., \& Byars, L. (2009). Management: Skills and Application (McGraw-Hill International Edition ed., 13th Edt.). New York: The McGraw-Hill International Companies.

Sakurai, K., \& Jex, S. M. (2012). Coworker incivility and incivility targets' work effort and counterproductive work behaviors: The moderating role of supervisor social support. Journal of Occupational Health Psychology, 17(2), 150.

Salvy, S. J., Bowker, J. C., Nitecki, L. A., Kluczynski, M. A., Germeroth, L. J., \& Roemmich, J. N. (2012). Effects of ostracism and social connection-related activities on adolescents' motivation to eat and energy intake. Journal of Pediatric Psychology, 37(1), 23-32.

Smith, A., \& Williams, K. D. (2004). R U there? Ostracism by cell phone text messages. Group Dynamics: Theory, Research, and Practice, 8(4), 291-301 
Sommer, K. L., Williams, K. D., Ciarocco, N. J., \& Baumeister, R. F. (2001). When silence speaks louder than words: Explorations into the intrapsychic and interpersonal consequences of social ostracism. Basic and Applied Social Psychology, 23(4), 225-243.

Stout, J. G., \& Dasgupta, N. (2011). When he doesn't mean you: Gender-exclusive language as ostracism. Personality and Social Psychology Bulletin, 37(6), 757-769.

Twenge, J. M., Catanese, K. R., \& Baumeister, R. F. (2002). Social exclusion causes self-defeating behavior. Journal of Personality and Social Psychology, 83(3), 606-615

Twenge, J. M., Catanese, K. R., \& Baumeister, R. F. (2003). Social exclusion and the deconstructed state: time perception, meaninglessness, lethargy, lack of emotion, and self-awareness. Journal of Personality and Social Psychology, 85(3), 409-423

Twyman, K. A., Saylor, C. F., Saia, D., Macias, M. M., Taylor, L. A., \& Spratt, E. (2010). Bullying and ostracism experiences in children with special health care needs. Journal of Developmental \& Behavioral Pediatrics, 31(1), 1-8.

Van Beest, I., \& Williams, K. D. (2006). When inclusion costs and ostracism pays, ostracism still hurts. Journal of Personality and Social Psychology, 91(5), 918-928.

Van Prooijen, J. W., Van den Bos, K., \& Wilke, H. A. (2004). Group belongingness and procedural justice: social inclusion and exclusion by peers affects the psychology of voice. Journal of Personality and Social Psychology, 87(1), 66-79.

Williams, K. D., \& Sommer, K. L. (1997). Social ostracism by coworkers: Does rejection lead to loafing or compensation?. Personality and Social Psychology Bulletin, 23(7), 693-706.

Williams, K. D. (2001). Ostracism: The power of silence. New York: The Guilford Press.

Williams, K. D., \& Nida, S. A. (2011). Ostracism consequences and coping. Current Directions in Psychological Science, 20(2), 71-75.

Williams, K. D. (2007). Ostracism: The kiss of social death. Social and Personality Psychology Compass, 1(1), 236-247.

Williams, K. D., \& Zadro, L. (2005). Ostracism: The Indiscriminate Early Detection System. In Williams, K. D., Forgas, J. P., \& Von Hippel, W. (Eds.). (2005). The social outcast: Ostracism, social exclusion, rejection, and bullying. Psychology Press. 19-34.

Williams, K. D., Cheung, C. K. T., \& Choi, W. (2000). Cyberostracism: Effects of being ignored over the internet. Journal of Personality and Social Psychology, 79(5), 748-762.

Williams, K. D., Govan, C. L., Croker, V., Tynan, D., Cruickshank, M., \& Lam, A. (2002). Investigations into differences between social-and cyberostracism. Group Dynamics: Theory, Research, and Practice, 6(1), 65-77.

Wittenbaum, G. M., Shulman, H. C., \& Braz, M. E. (2010). Social ostracism in task groups: The effects of group composition. Small Group Research, 41(3), 330-353. 


\section{Macrothink}

International Journal of Human Resource Studies

ISSN 2162-3058 2016, Vol. 6, No. 4

Wu, L. Z., Yim, F. H. K., Kwan, H. K., \& Zhang, X. (2012). Coping with workplace ostracism: The roles of ingratiation and political skill in employee psychological distress. Journal of Management Studies, 49(1), 178-199.

Wu, L., Wei, L., \& Hui, C. (2011). Dispositional antecedents and consequences of workplace ostracism: An empirical examination. Frontiers of Business Research in China, 5(1), 23-44.

Yeo, G. B., \& Neal, A. (2004). A multilevel analysis of effort, practice, and performance: effects; of ability, conscientiousness, and goal orientation. Journal of Applied Psychology, 89(2), 231.

Zadro, L., Boland, C., \& Richardson, R. (2006). How long does it last? The persistence of the effects of ostracism in the socially anxious. Journal of Experimental Social Psychology, 42(5), 692-697.

\section{Copyright Disclaimer}

Copyright for this article is retained by the author(s), with first publication rights granted to the journal.

This is an open-access article distributed under the terms and conditions of the Creative Commons Attribution license (http://creativecommons.org/licenses/by/3.0/). 